\title{
Implikasi Fluktuasi Suku Bunga dan Kurs Terhadap Iklim Investasi di Indonesia
}

\author{
Arif Fadilla ${ }^{1^{*}}$, Novi Permata Indah ${ }^{2}$ \\ ${ }^{1,2}$ Program Studi Manajeman, Universitas Singaperbangsa Karawang \\ Jl. HS. Ronggo Waluyo Paseurjaya, Karawang, Jawa Barat 41361 Indonesia \\ *e-mail :ariffadila@fe.unsika.ac.id
}

\begin{abstract}
$\overline{\text { ABSTRAK }}$
Artikel Info

Received :

29 September 2019

Revised :

04 Februari 2020

Accepted :

09 Juni 2020

Penelitian ini bertujuan untuk menguji dampak fluktuasi suku bunga Bank Indonesia dan kurs Rupiah IDR/USD terhadap iklim investasi di Indonesia. Iklim investasi di Indonesia diukur dengan Indeks Harga Saham Gabungan (IHSG). Objek dalam penelitian ini adalah data runtun waktu dari IHSG, suku bunga dan kurs Rupiah terhadap Dollar Amerika. Data runtun waktu yang akan dijadikan objek penelitan merupakan data time series periode Januari 2014-Agustus 2019. Penelitian ini, menggunakan analisis regresi linier berganda untuk teknik pengolahan data. Hasil penelitian menunjukkan bahwa baik suku bunga dan kurs Rupiah/USD tidak berpengaruh signifikan terhadap perubahan IHSG. Besar pengaruh suku bunga dan kurs Rupiah/USD terhadap IHSG masing masing adalah $-0,213$ dan 0,92. Hasil tersebut menunjukkan bahwa peningkatan kurs rupiah/USD akan meningkatkan IHSG, sedangkan peningkatan suku bunga akan menurunkan IHSG. Penelitian ini juga menemukan bahwa lebih dari $60 \%$ IHSG dipengaruhi oleh kedua faktor makroekonomi yang diteliti. Hal ini dapat dilihat dari proporsi variansi pengaruh suku bunga dan kurs terhadap IHSG sebesar61,4\%.
\end{abstract}

Kata kunci: Suku Bunga, IHSG, kurs.

\section{Implications of Interest Rate And Exchange Rate Fluctuations Investment Climate In Indonesia}

\section{ABSTRACT}

This study aims to examine the impact of interest rate fluctuations measured by the interest rate and IDR/USD exchange rate on the investment climatee in Indonesia. The investment climate in Indonesia is measured by the Compositee Stock Pricee Index (CSPI). The objects ini this study are the time series data from the $C S P I$, the interest rate and the exchange rate of IDR/USD. The time series data that will be used as the object of research are time series data from January 2014 to August 2019. The aanalysis technique used is multiple linear regression analysis. The results showed that both the interest rate and the exchange rate had note significant effect on changes in the valuee of the CSPI. The 
influence of the interest rateand IDR/USD exchange rates on the CSPI were -0.2133 and 0.92 . These results indicate that an increase in the exchange rate of IDR/USD will increase the value of the CSPI, while an increase in the interest rates will decrease the valuee of the CSPI. The study also found that more than $60 \%$ off the Composites Stock Prices Index was influenced by the two macroeconomic factors studied. This can bee seen from the proportion of the variance off the effect of the interest rate and the exchange rates on the CSPI of $61.4 \%$.

Keywords : Interest Rate, CSPI, Exchange Rate.

\section{PENDAHULUAN}

Perekonomian Indonesia mulai bangkit kembali setelah mengalami krisis moneter pada tahun 1997-1998, indikator kebangkitan ekonomi Indonesia ditandai mulai menggeliatnya iklim investasi di Bursa Saham dari triwulan pertama tahun 2000. Transaksi volume penjualan saham di Bursa Efek Indonesia meningkat dan adanya kebijakan restruturisasi utang yang berimplikasi pada turunnya rasio utang terhadap ekuitas dan pada saat bersaman harga saham mengalami kenaikan (Kompas 2003).

Bursa Efek Indonesia sebagai lembaga bursa menjalankan misi;"menyediakan infrastruktur untuk mendukung terselenggaranya perdagangan efek yang teratur, wajar, dan efisien serta mudah diakses oleh seluruh pemangku kepentingan (stakeholders)". Sebagai pasar bertemunyademanddan supply berbagai produk dalam bentuk surat utang, obligasi, derivatif, exchange trade fund (ETF) dan saham, pasar modal harus menjadi lokomotif terdepan dalam menggerakkan roda perekonomian negara khususnya investasi. Indikator membaiknya investasi ditandai dengan terjadinya peningkatan (bullish) indeks harga saham, dan jika terjadi penurunan (bearihs) transaksi jual beli saham maka dapat disimpulkan terjadi penurunan investasi atau indeks harga saham turun, ini terjadi karena pengaruh indikator-indikator makro ekonomi juga sedang mengalami penurunan.

Bagi pelaku pasar, indeks harga saham merupakan salah satu ukuran berinvestasi atau tidak selain kursvalas, sebab pergerakan indeks akan merubah persepsi pelaku pasar apakah akan membeli, menahan atau melepas sahamnya dan indeks di bursa saham dijadikan sebagai barometer ekonomi sebuah negara. Fluktuasi indeks saham pada bursa satu negara menggambarkan kinerja perekonomian (khususnya sektor investasi) jika Indeks Harga Saham Gabungan naik berarti iklim investasi di negara tersebut membaik dan negara tersebut aman bagi investor untuk menanamkan modalnya. Memburuknya indeks saham sebuah negara dapat dikatakan rapuhnya fundamental ekonomi dan investor akan berhati-hati menanamkan modalnya di negara tersebut.

Bagi para pelaku pasar, banyak faktor yang mempengaruhi mereka untuk mengambil keputusan menanamkan modalnya, seperti asumsi makro ekonomi, stabilitas politik nasional, fluktuasi suku bunga, indeks saham negara lain dan lain-lain. Jika salah satu faktor tersebut berubah secara ekstrim maka indeks harga saham gabungan bisa terjun bebas, maka dengan demikian para pengambil kebijakan ekonomi sangat berhati-hati dalam mengambil keputusan penetapan suku bunga, pengendalian inflasi, dan stabilitasi moneter. 


\section{KAJIAN TEORI}

\section{Indeks Harga Saham Gabungan (IHSG)}

Secara teoritis, fluktuasi IHSG menggambarkan pergerakan harga saham atau naik dan turunnya investasi di pasar modal berfungsi sebagai; Pertama, penanda arah pergerakan pasar. Kedua, mengukur keuntungan, dan ketiga tolok ukur kinerja portofolio investasi (Warta Ekonomi, 2019).

Menurut Tandelin (2001) indikator yang dapat mempengaruhi kondisi pasar modal adalah Produk Domestik Bruto (PDB), inflasi, suku bunga, dan nilai tukar mata uang/kurs (exchange rate). Sedangkan dampak variabel makro ekonomi terhadap investasi dapat digambarkan pada tabel 1 berikut ini (Tandelin dan Eduardus, 2000).

Tabel 1. Pengaruh Indikator Makro Ekonomi Terhadap Investasi

\begin{tabular}{clrl}
\hline Indikator & \multicolumn{2}{c}{ Dampak } & \multicolumn{2}{c}{ Penjelasan } \\
\hline Kurs rupiah & Jika kurs rupiah menguat & Jika kurs Rupiah turun terhadap \\
& terhadap valasartinya menjadi & valas maka dapat meningkatkan \\
& sinyal positif bagi ekonomi yang & biaya impor bahan baku, dan \\
mengalamiinflasi & & menaikkan suku bunga, ekspor \\
& & naik
\end{tabular}

Suku bunga Jika suku bunga naik berarti Jika suku bunga naik maka biaya sinyal positif bagi investor di modal naik. Biaya modal naik, pasar modal terjadi perpindahan investasi dari saham ke deposito atau fixed

Dari hubungan antar variabel di atas maka dapat dirumuskan kerangka pemikiran dari sebagai berikut:

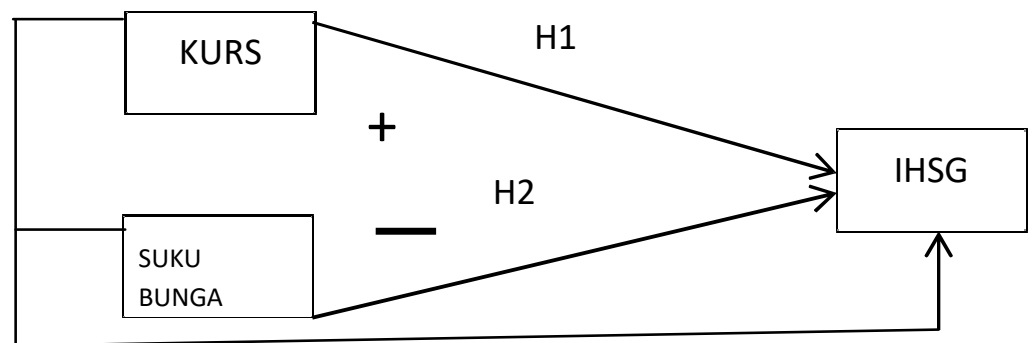

H3

Gambar 2. Kerangka Pemikiran

\section{Suku bunga}

Penetapan tingkat suku bunga (interest rate) digunakan sebagai instrumen kebijakan moneter yang bertujuan mengendalikan jumlah uang beredar dan inflasi. Suku bunga ditetapkan oleh Dewan Gubernur Bank Indonesia selaku pemegang otoritas moneter Indonesia setiap bulan (Bank Indonesia, 2017). Dan penetapan suku bunga juga bertujuan untuk menjaga liquiditas di pasar modal dengan mengatur suku bunga. Apabila Bank Indonesia menaikkan suku bunga maka jumlah uang beredar turun dan pada saat suku bunga diturunkan maka jumlah uang beredar naik. Saat suku bunga turun sektor perbankan akan menambah pinjaman kepada bank sentral sebagai fasilitas berjaga-jaga (lending facility) atau meminjam uang kepada sesama bank (standing facility) dengan menggunakan suku bunga Pasar Uang Antar Bank (PUAB) overnigh. Operasi Pasar Terbuka yang 
selanjutnya disebut OPT merupakan kegiatan transaksi di pasar uang yang dilakukan atas inisiatif Bank Indonesia dalam rangka mengurangi (smoothing) volatilitas sukubunga PUAB o/n (Bank Indonesia, 2019). Pergerakan suku bunga PUAB biasanya diikuti oleh pergerakan suku bunga deposito dan suku bunga pinjaman di sektor riil.

Dengan demikian, kebijakan moneter melalui penetapan suku bunga sangat mempengaruh liquiditas perbankan dalam jangka pendek dan cukup efektif untuk mendinginkan suhu perekonomian. Karena apabila suku bunga rendah keinginan masyarakat untuk berinvestasi rendah, jumlah uang beredar tinggi akan mendorong konsumsi secara keseluruhan (agregat consumption) naik dan mendorong inflasi. Di pasar modal, tingginya suku bunga medorong pelaku pasar modal membeli uang negara yang menaikkan suku bunga untuk mendapatkan capital gain sebagai reaksi jangka pendek. Menurut Dauda, (2011) instrument pasar modal suku bunga menjadi (investment fasilitate) acuan investasi. Selain itu, terdapat hubungan erat antara suku bunga dengan inflasi dimana jika suku bunga rendah inflasi tinggi dan jika suku bunga tinggi inflasi tinggi karena masyarakat menyimpan sebagian konsumsinya menjadi tabungan.

\section{Kurs Rupiah/USDd}

Mankiw et.al (2012)membagi kurs menjadikurs nominal dan kurs riil:

1. Kurs nominal (Nominal ExchangeRate)

Kurs yang tertera pada fisik uang digunakan sebagai komoditi yang diperjual belikan dengan valuta asing.

2. Kurs Riil (Real ExchangeRate)

Adalah kurs nominal yang bisa ditukarkan dengan sejumlah barang dan jasa dari suatu negara dengan barang dan jasa atau perbandingan perbandingan antara kurs nominal uang dengan harga.

Kurs Rupiah terdepresiasi apabila kursvaluta asing naik di pasar modal, dan terapresiasi apabila kurs valuta asing (valas) turun atau kurs mata uang domestik relatif menurun terhadap valas. Perubahan kurs valas disebabkan karena adanya perubahan permintaan atau penawaran dalam bursa valas. Fluktuasi kurs ini disebabkan oleh perubahan permintaan dan penawaran uang di pasar modal.

\section{METODE}

Penelitian ini merupakan penelitian deskriptif kuantitatif terhadap data runtun waktu dari IHSG, suku bunga, dan kurs Rupiah terhadap USD. Data Variabel penelitian indeks saham diambil dari laporan statistik bulanan Bursa Efek Indonesia dan data variabel suku bunga, kurs, dikutip dari situs resmi Bank Indonesia. Data time series yag diteliti berlangsung dari periode Januari 2014-Desember 2018 dan diolah dengan menggunakan analisis regresi linier dengan teknik ordinary least square, meminimalkan galat dalam proses regresi. Tujuan dari analisis regresi degan teknik ordinary least square ini adalah untuk melihat pengaruh dua variabel atau lebih.

Sering kali dalam masalah ekonomi kita berhadapan dengan persoalan yang menyangkut sekelompok variabel, dan diantara variabel tersebut terdapat suatu hubungan saling pengaruh secara alamiah. Sudut pandang statistika melihat persoalan tersebut sebagai taksiran hubungan antar sekelompok variabel. Model matematik yang biasa digunakan untuk mengukur besarnya pengaruh variabel bebas terhadap variabel respon terhadap data percobaan adalah persamaan regresi dimana:

Keterangan,

$$
y=a+b_{1} x_{1}+b_{2}+x_{2}+e
$$




\section{EKONOMIKAWAN : Jurnal Ilmu Ekonomi dan Studi Pembangunan}

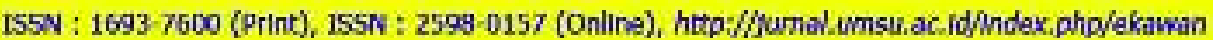

$y \quad$ : Indeks Harga Saham Gabungan (IHSG)

a : konstanta

$b, b_{2} \quad:$ koefisien regresi

$x_{1} \quad$ : Suku bunga

$x_{2} \quad:$ Kurs

e : galat berikut:

Uji asumsi residual dalam analisis regresi harus memenuhi beberapa syarat sebagai

1. Uji Kenormalan

Uji kenormalan dalam penelitian ini menggunakan uji Kolmogorov-Smirnov. Kriteria pengujian yang digunakan adalah Nilai P-value. Jika Nilai P-value lebih kecil dari kesalahan $\alpha$ sebesar 5\%, maka tolak H0. Sehingga jika H0 ditolak dapat disimpulkan bahwa residual dari model regresi tidak berdistribusi normal.

2. Uji Residual Identik

Uji ini untuk melihat apakah residual homoskedastik dari variansi residual. Artinya, variabel pengganggu memiliki ragam yang sama. Teknik yang digunakan dalam melihat apakah terdapat residu menyebar secara homogen atau heterogen,peneliti menggunakan pendekatan visual dengan membuat scatter plot graffic antara fitted value dengan residual. Dimana Y (Nilai Y) yang telah diprediksi dan sumbu X sebagai residual $(\hat{-}-Y)$. Pola pada grafik scatter plot menggambarkan bahwa terdapat residual heteroskedasitas atau tidak.

3. Uji Kebebasan Residual

Disebut juga sebagai uji Durbin-Watson, untuk mengukur korelasi variabel yang berbeda dalam rentang waktu, apakah dapat dideteksi atau tidak autokorelasi pada nilai residual (prediction errors). Hipotesanya adalah $\mathrm{H} 0$ ditolak apabila $d w<d l$. Nilai $d l$ dengan $\alpha$ sebesar $5 \%$.

4. Uji Non Multikolinearitas

Uji ini digunakan untuk melihat korelasi antara dua variabel bebas atau lebih dalam sebuah model regresi berganda. Dalam uji non multikolinearitas variabel prediktor harus saling bebas antara satu dengan yang lainnya. Pendeteksian multikolinieritas dengan melihat nilai VIF (Variance Inflation Factor), jikanilai VIF $\leq 10$ maka tidak terjadi multikolinieritas, jika nilai VIF > 10 maka terjadi multikolinieritas.

\section{HASIL DAN PEMBAHASAN}

Hasil pengujian data secara deskriptif dapat dilihat pada Tabel 2.

Tabel 2. IHSG, Kurs, Inflasi, dan SukuBunga

\begin{tabular}{lccc}
$\begin{array}{l}\text { Deskriptif } \\
\text { Statistik }\end{array}$ & $\begin{array}{c}\text { IHSG } \\
\text { (Rp) }\end{array}$ & $\begin{array}{c}\text { Suku } \\
\text { bung } \\
\text { a (\%) }\end{array}$ & $\begin{array}{c}\text { Kurs } \\
\text { (Rp) }\end{array}$ \\
\hline Minimum & $4,223.91$ & 4.25 & 11,404 \\
Maksimum & $6,605.63$ & 7.75 & 15,227 \\
Rata-rata & $5,474.45$ & 6.04 & 13,374 \\
Standar Deviasi & 639.66799 & 1.2623953 & 861.0082 \\
$\mathrm{n}$ & 68 & 68 & 68 \\
\hline
\end{tabular}


I55N : $1693-7600$ (Print), $155 N$ : $2598-0157$ (Online), http://Jumalumstiac.id/index.php/ekawan

\section{Uji Asumsi Klasik}

Untuk menguji keabsahan data pada penelitian regresi maka harus terlebih dahulu memenuhi uji asumsi klasik supaya diperoleh model regresi dengan estimasi yang tidak bias dan pengujian dapat dipercaya. Uji asumsi klasik yang digunakan yaitu normalitas, mulltikolinieritas, autokolerasi, dan heteroskedastisitas. Apabila ada satu syarat saja tidak terpenuhi, hasil analisis regresi tidak dapat dikatan bersifat BLUE (Best Linear Unbiased Estimator).

\section{a. Uji Normalitas}

Menurutt Duwi Priyatno (2014:90) Uji inormalitas pada model regresi digunakan untuk menguji apakah nilai residual yang dihasilkan dari regresi terdistribusi secara normal atau tidak. Berikut ujii normalitas dengan One Sample Kolmogorov-Smirnov.

1. Jika nilai signifikansi $>0.05$ maka distribusi residual terdistribusinormal.

2. Jika nilai signifikansi $<0.05$ maka distribusi residual tidak berdistribusi secara normal.

Tabel 3. Uji Normalitas One-Sample Kolmogorov-Smirnov Test

\begin{tabular}{llr}
\hline & & $\begin{array}{r}\text { Unstandardize } \\
\text { d Residual }\end{array}$ \\
\hline $\mathrm{N}$ & Mean & 6 \\
Normal Parameters ${ }^{\mathrm{a}, \mathrm{b}}$ & Std. &, 0000000 \\
& Deviation &, 07293697 \\
Most Extreme Differences & Absolute &, 175 \\
& Positivee &, 175 \\
Test Statisticc & Negativee &,- 142 \\
Asymp. Sig. (2-tailed) & &, 175 \\
\hline
\end{tabular}

Test distribution is normal.

Sumber: Hasil Pengolahan Data SPSS 25, 2019.

Hasil Uji One Sample Kolmogorov-Smirnov pada tabel uji normalitas menunjukan nilai signifikansi (Asymp. Sig. 2-tailed) sebesar 0,200. Karena nilai signifikansi 0,200> 0,05 dapat disimpulkan bahwa nilai residual terdistribusi secara normal.

\section{b. Uji Multikolinieritas}

Uji multikolinieritas digunakan untuk mengetahuii adanya hubungan antar variabel independen yang terdapat dalam model regresi. Model regresi yang baik seharusnya tidak terjadi multikolinieritas.

Metode yang digunakan untuk menguji adanya multikolinieritas dalam penelitian ini dengann melihat nilaiiVariance Inflantion Factor (VIF) dan Tolerance, apabila nilai VIF kurang dari 10 dan Tolerance lebih dari 0,1 maka dinyatakan tidak terjadi multikolinieritas. 
Published, Volume 20 No. 1, Juli 2020

EKONOMIKAWAN : Jurnal IImu Ekonomi dan Studi Pembangunan

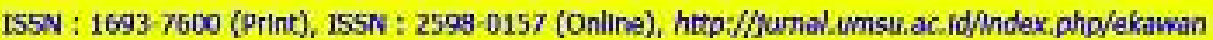

Tabel 4. Uji Multikolinieritas

\begin{tabular}{|c|c|c|c|c|c|c|c|}
\hline & \multicolumn{2}{|c|}{$\begin{array}{c}\text { Unstandardized } \\
\text { Coefficients }\end{array}$} & \multirow{2}{*}{$\begin{array}{c}\text { Standardized } \\
\text { Coefficients }\end{array}$} & \multirow{2}{*}{$\mathrm{t}$} & \multirow{2}{*}{ Sig. } & \multicolumn{2}{|c|}{$\begin{array}{c}\text { Collinearity } \\
\text { Statistics }\end{array}$} \\
\hline Model & B & Std. Error & & & & Tolerance & VIF \\
\hline 1 (Constant) & ,247 & 7,586 & & ,033 & ,976 & & \\
\hline $\begin{array}{l}\text { Data Kurs Rp } \\
\text { terhadap } \\
\text { Dolar }\end{array}$ & ,920 & ,772 &, 513 & 1,192 & ,319 & ,694 & 1,441 \\
\hline $\begin{array}{l}\text { Data BI - Rate } \\
(\%)\end{array}$ &,- 213 & ,247 &,- 372 &,- 865 & ,451 & ,694 & 1,441 \\
\hline
\end{tabular}

Sumber: Hasil pengolahan data SPSS 25, 2019.

Berdasarkan tabel uji multikolinieritas bisadisimpulkan nilai tolerance variabel bebas lebih dari 0,1 dan VIF kurang dari 10, maka dapat disimpulkan bahwa tidak terjadi multikolinieritas antar variabelindependen.

\section{c. Uji Autokorelasi}

Menurut Suharyadi \& Purwanto, (2016:248) bahwa autokorelasi yaitu adanya korelasi antara data pengamatan. Pengujian autokorelasi yaitu dengan melakukan Uji Run. Menurut Santoso (2017:393) bahwa Uji Runssatau bisa disebut ujii sampel rangkaian tunggal untuk memeriksa keacakan, pada prinsipnya ingin mengetahui apakah suatu rangkaian kejadian, hal atau symbol merupakan hasil proses yang acak (random), dalam arti tidak direncanakan terlebih dahulu, atau tidak membuat sebuah pola tertentu. berikut:

Pengujian autokorelasi menggunakan Uji Runs Test dengan ketentuan sebagai

- Jika probabilitas $>0,05$ maka residual tidak terjadi autokorelasi

- Jika probabilitas $<0,05$ maka residual terjadi autokorelasi.

Tabel 5. Uji Autokorelasi Runs Test

\begin{tabular}{lr}
\hline Test Value $^{\mathrm{a}}$ &, 00491 \\
Cases $<$ Test Value & 3 \\
Cases $>=$ Test Value & 3 \\
Total Cases & 6 \\
Number of Runs & 3 \\
Z &,- 456 \\
Asymp. Sig. (2-tailed) &, 648 \\
\hline Sumber: Hasil pengolahan data SPSS 25, 2019.
\end{tabular}


Berdasarkan hasil uji autokorelasi menggunakan Run Test diperoleh hasil signifikan sebesar 0,648 lebih besar dari 0,05 ini berarti antara residual tidak terjadi autokorelasi.

\section{d. Uji Heteroskedastisitas}

Uji heteroskedastisitas digunakan untuk mengetahui varian residual dari data pengamatan pada model regresi. Regresi yang baik seharusnya tidak terjadi heteroskedastisitas. Adapun untuk mendeteksi adanya heteroskedastisitas dengan menggunakan metode grafik, dimana:

a. Jika adaapola tertentu seperti titik-titik yang ada membentuk suatu pola tertentu yang teratur (bergelombang, melebar dan nmenyempit), maka terjadi heteroskedastisitas.

b. Jika tidak ada pola yang jelas, seperti titik-titik menyebar di atas dan di bawah angka 0 pada sumbu Y, maka tidak terjadi heteroskedastisitas.

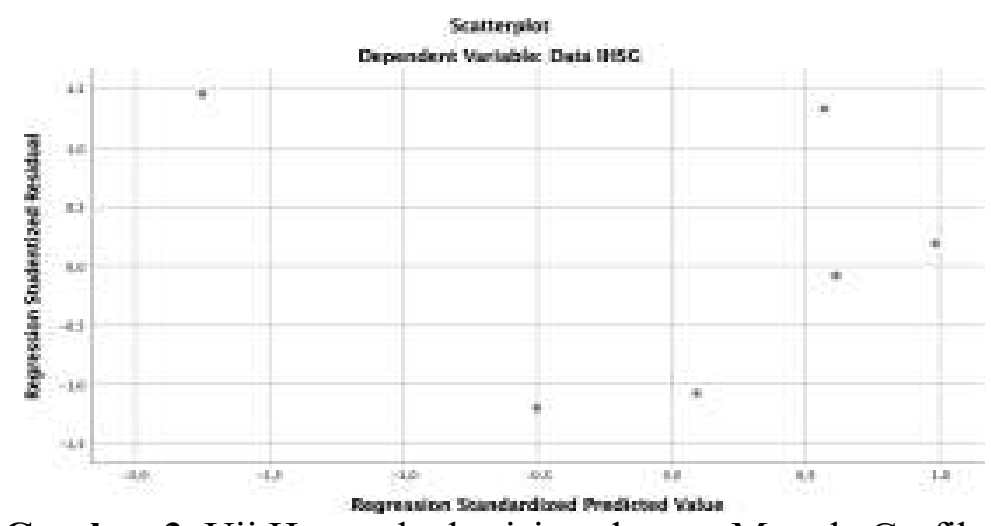

Gambar 3. Uji Heteroskedastisitas dengan Metode Grafik

Dari output di atas dapat diketahui titik-titik tidak membentuk pola yang jelas dan titik- titik menyebar di atas dan di bawah angka 0 pada sumbu Y. Jadi bisa disimpulkan bahwa tidak terjadi masalah heteroskedastisitas pada model regresi.

\section{Analisis Kelayakan Model}

Hasil uji t terhadap data pada tabel 3 dapat dilihat pengaruh simultan variabel bebas terhadap variabel terikat. Hasil pengolahan data didapat bahwa varibel kurs tidak berpengaruh signifikan terdapatt IHSG. Dimana nilai p-value variabel kurs sebesar 0,319 lebih besar dari kesalahan 5\% dan besarnya pengaruh variabel kurs terhadap IHSG didapat sebesar 0,920 .

Hasil uji untuk mengukur pengaruh variabel suku bunga terhadap IHSG menunjukan bahwa suku bunga tidak berpengaruh signifikan terhadap IHSG. Nilai p-value statistik uji $\mathrm{t}$ lebih besar dari kesalahan yaitu 0,451. Besar pengaruh suku bunga terhadap IHSG yaitu 0,213 .

Sedangkan koefisien regresi pengaruh kursrRupiah/USD dan suku bunga terhadap IHSG dapat dilihat pada persamaan berikut

$$
Y=0,247-0,213 x_{1}+0,920 x_{2}+e
$$

Persamaan regresi di atas menunjukkan bahwa secara simultan variabel kurs, inflasi, dan Suku bunga terhadap IHSG berpengaruh signifikan. Dimana uji statistic F menunjukan nilai 00,24 yang lebih besar dari kesalahan sebesar 5\%. 
I55N : $1693-7600$ (Print), $155 N$ : $2598-0157$ (Online), http://Jumalumstiac.id/index.php/ekawan

Tabel 6. Ringkasan Uji Keccokan Model

\begin{tabular}{rr|r|r|r|c}
\hline Model & $\mathrm{R}$ & R Square & $\begin{array}{c}\text { Adjusted R } \\
\text { Square }\end{array}$ & $\begin{array}{c}\text { Std. Error of the } \\
\text { Estimate }\end{array}$ & Durbin-Watson \\
\hline 1 &, $783^{\mathrm{a}}$ &, 614 &, 356 &, 09416 & 1,188 \\
\hline
\end{tabular}

Parameter yang dipakai dalam melihat adanya kesesuaian model regresi adalah besaran koefisian determinasi. Hasil penelitian menunjukkan bahwa $R^{2}=0,614$ artinya $61,4 \%$ IHSG dipengaruhi oleh variabel suku bunga dan kurs.

\section{SIMPULAN}

1. Suku Bunga dan kurs Rupiah IDR/USD tidak berpengaruh signifikan terhadap Indeks Harga Saham Gabungan.

2. Pengaruh Suku Bunga dan Kurs Rupiah IDR/USD masing-masing terhadap Indeks Harga Saham Gabungan adalah 0,92 dan -0,213.

3. Proporsi variasi total pengaruh Suku Bunga dan Kurs Rupiah IDR/USD terhadap Indeks Harga Saham Gabungan sebesar 61,4\%.

\section{DAFTAR PUSTAKA}

Bank Indonesia. (2017). Indonesia Financial Statistik. Jakarta : BI.

Bursa Efek Indonesia. (2008). Buku Panduan Indeks Harga Saham Bursa Efek Indonesia. Jakarta : BEI.

Deitiana, Tita. (2011). Pengaruh Rasio Keuangan, Pertumbuhan Penjualan dan Deviden Terhadap Harga Saham. Jurnal Bisnis dan Akuntansi, Voleme 13, No. 1, Hal. 57-66.

Kewal, Suramaya Suci. (2012). Pengaruh Inflasi, Suku Bunga, dan Pertumbuhan PDB Terhadap Indeks Harga Saham Gabungan. Jurnal Economia, Volume 8, Nomor 1. Hal 53-64.

Mankiw. N, Quah. E, dan Wilson. P. (2012). Pengantar Ekonomi Makro. Jakarta : Salemba empat.

Manurung, Ria. (2016). Pengaruh Inflasi, Suku Bunga dan Kurs Terhadap Indeks Harga Saham Gabungan pada Bursa Efek Indonesia. Jurnal Ekonom, Volume 19, No. 4. Hall48-156.

Mardiyati, Umi dan Ayi Rosalina. (2013). Analisis Pengaruh Nilai Tukar, Tingkat Suku Bunga dan Inflasi Terhadap Indeks Harga Saham : Studi Kasus pada Perusahaan Properti yang Terdaftar di Bursa Efek Indonesia. Jurnal Riset Manajemen Sains Indonesia (JRMSI), Volume 4, No. 1.hal. 1-15.

Mishkin, S. Frederic. (2006). Ekonomi Uang dan Pasar Keuangan. Jakarta : Salemba empat.

Permana, Yogi. (2009). Pengaruh Fundamental Keuangan, Tingkat Bunga, dan Tingkat Inflasi Terhadap Pergerakan Harga Saham. Jurnal Akuntasi Universitas Gunadarma. September 2009.

Tandelin, Eduardus. (2000). Pasar Modal Indonesia: Problem dan Prospek. Wahana, Volume 3, No. 2.

Tandelin, Eduardus. (2001). Analisis Investasi Manajemen Portofolio, Cetakan Pertama, Yogyakarta : BPFE. 